\title{
Effect of $0.2 \%$ Hyaluronic Acid Gel Topical Application on Healing Period of Oroantral Fistula Treated with Buccal Flap
}

\author{
Nawres Bahaa Mohammed ${ }^{1}$, Malath Azeez Alsaadi ${ }^{2 \star}$, Safaa Sahib Naji Sultan ${ }^{3}$, Adil Aliakbar $^{4}$ \\ ${ }^{1}$ Department of Oral and Maxillofacial Surgery, University of Al Ameed, Kerbala, Iraq; ${ }^{2}$ Department of Pharmacology and \\ Toxicology, College of Dentistry, University of Babylon, Hillah, Iraq; ${ }^{3}$ Department of Surgery, College of Medicine, University of \\ Babylon, Hillah, Iraq; ${ }^{4}$ Department of Surgery, College of Medicine, University of Babylon, Babil, Iraq
}

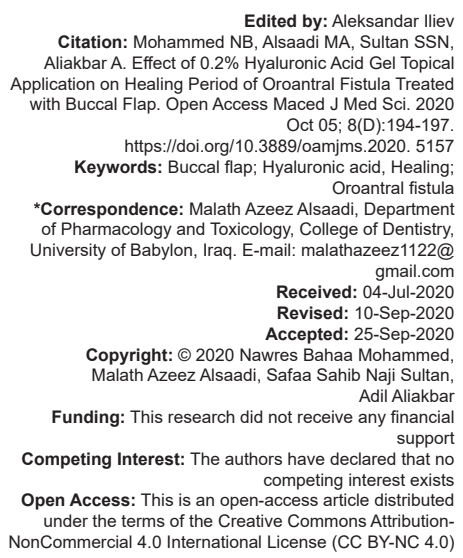

\section{Introduction}

Oroantral fistula (OAF) is a connection between maxillary sinus and oral cavity started as opening result from maxillary posterior teeth extraction, dental infections, osteomyelitis, radiation therapy, or trauma [1], [2]. Failure of immediate management of that opening leads to pathological duct with epithelial lining and granulation tissue filling termed fistula [3].

The presence of OAF might cause inflammation of the maxillary sinus and infection due to oral bacteria and food debris escape from oral cavity that requires more treatment that is complicated [4].

Management of OAF depend on the size, chronicity, and degree of maxillary sinus involvement, generally different techniques available such as buccal or palatal flap, bone graft, platelet-rich fibrin (PRF) clot, and PRF membrane and others [5], [6], [7].

OAF closure by tissue flaps has wide area in clinical practice, especially in mild and moderate size fistula. Buccal flap widely used because of easy, quick, and low failure rate, however, buccal flap associated with post-operative pain, swelling, and decrease of buccal sulcus, which trouble the use of prosthesis in the future [8], [9].

Hyaluronic acid $(\mathrm{HA})$ is a polymer of glucuronic acid and $\mathrm{N}$-acetylglucosamine disaccharide that found in many tissues such as eye, skin, joints, and other tissue. HA plays crucial role in connective tissue integrity and elasticity that favorite the use of it in various pharmaceutical preparations [10], [11].

The therapeutic advantages of HA proved in various surgical and non-surgical fields due its ability to promote healing, reduce infection in addition to induction of fibroblast proliferation and angiogenesis [12].

In dental practice, HA used topically for the treatment of periodontitis twice daily for a month reduce inflammatory process and improve the state according to a study made by Mesa et al. [13].

Another study done by Koray et al. [14] found that applying $0.2 \%$ HA spray 3 times a day, for 7 days after a surgery for impacted third molar to the extraction area, reduce swelling and trismus throughout the postoperative period. 
The aim of the current study was to evaluate the effect of HA gel topical application on pain, swelling, and healing period of OAF treated surgically by buccal flap.

\section{Methods}

This is a retrospective study conducted to evaluate the effect of topical HA gel on the healing of OAF treated by buccal flap compared with patients treated without HA gel application during the period from March to December 2018. The records of patients treated by one maxillofacial surgeon in AL-Hilla Teaching Hospital maxillofacial clinic evaluated retrospectively.

\section{Patients}

Twenty patients of both sexes included in study all of them have chronic OAF treated by surgical buccal flap. Ten of them received HA gel applied directly after suturing and instructed to apply twice daily until suture removal, while the other 10 patients were without HA gel (Table 1).

Healing evaluated during suture removal appointment by clinical examination.

Outcomes are as follows:

- $\quad$ Decrease rate of dehiscence and suture failure

- Decrease gingival inflammation

- $\quad$ Adverse reactions and infection

- Healing period.

\section{Inclusion criteria}

Traumatic tooth extraction with immediate opening more than $4 \mathrm{~mm}$ and patients with acute fistula more than $4 \mathrm{~mm}$ included in the study.

\section{Exclusion criteria}

The following criteria were excluded from the study:

- $\quad$ Patients with osteomyelitis

- $\quad$ Patients with tumors

- $\quad$ Patients with syphilis

- $\quad$ Patients with osteoradionecrosis

- $\quad$ Patients with mucormycosis.

\section{Treatments}

\section{Buccal flap technique}

All patients treated with Rehrmann [15] buccal advancement flap in which two divergent incisions made in the buccal side of the alveolus the horizontal release made to release the periosteum to allow advancement and closure of OAF without tension.

\section{Post-operative treatments and instructions}

All patients prescribed with antibiotics, analgesia, and nasal decongestant. Patients were instructed to wear surgical stent for 7-10 days and a date of suture removal was set at day 14 . Patients were clinically examined at days 7,10 , and 14 .

\section{Instructions}

Patients with HA gel advised to apply the gel twice daily for 14 days.

Patients of both groups instructed to stop smoking, avoid nose blowing and open mouth widely while sneezing.

Drugs

- HA gel 0.2\%, GEGIGEL (Ricerfarma Gengigel Gingival Gel $20 \mathrm{ml}$, EU).

Paracetamol $500 \mathrm{mg}$ tablet, Panadol (GlaxoSmithKline, UK).

- $\quad$ Amoxicillin + clavulanic acid oral tablet $1000 \mathrm{mg}$ (CoAmox Acino, Acino Pharma, Switzerland). Xylometazoline nasal decongestant.

\section{Statistical analysis}

The data evaluated at the level of significant of $\leq 0.05$ by independent sample t-test and one-way ANOVA using IBM SPSS Statistics software 23.

\section{Results}

Evaluation of 20 patients had oroantral fistula treated with buccal flap show significant $p \leq 0.05$ decrease in healing period when we compare patients

Table 1: Distribution of patients included in the study according to gender and area of OAF

\begin{tabular}{|c|c|c|c|c|c|c|c|}
\hline \multirow[t]{2}{*}{ Groups } & \multirow[t]{2}{*}{ Numbers } & \multirow[t]{2}{*}{ Male no. } & \multirow[t]{2}{*}{ Female no. } & \multicolumn{4}{|c|}{ Area of oroantral fistula } \\
\hline & & & & $1^{\text {st }}$ molar no. & $2^{\text {nd }}$ molar no. & $1^{\text {st }}$ pre molar no. & $2^{\text {nd }}$ premolar no. \\
\hline Patients treated with $\mathrm{HA}$ & 10 & 4 & 6 & 2 & 2 & 2 & 4 \\
\hline Patients treated with $\mathrm{HA}$ & 10 & 4 & 6 & 2 & 2 & 2 & 4 \\
\hline
\end{tabular}


treated with topical HA gel $(\mathrm{HA})$ and those without topical HA gel (Table 2).

Table 2: Differences in healing time between patients treated with HA and those treated without HA

\begin{tabular}{lllllll}
\hline Criteria & Groups & $\mathrm{n}$ & Mean & $\begin{array}{l}\text { Std. } \\
\text { deviation }\end{array}$ & $\begin{array}{l}\text { Std. error } \\
\text { mean }\end{array}$ & $\mathrm{p}$-value \\
\hline Healing time & With HA & 10 & 10.0000 & 1.49071 & 0.47140 & $0.000 \leq 0.05^{*}$ \\
& Without HA & 10 & 19.4000 & 1.50555 & 0.47610 & \\
\hline${ }^{*} \mathrm{p} \leq 0.05$. HA: Hyaluronic acid. & & & & &
\end{tabular}

Patients of both group show no dehiscence or suture failure at surgical site when inspected at day 14 (suture removal appointment) and neither of them show sign of infection too.

On the other hand, gingival enlargement decreased and about to be resolved completely in patients treated with topical HA gel than those without topical HA gel during clinical examination appointments at days 7 and 10 with complete healing observed at suture removal appointment (day 14).

No significant differences in healing period observed between male and female patients of both treatment groups $p \geq 0.05$, Table 3 .

Table 3: Differences in healing period between male and female of both treatment groups

\begin{tabular}{lllllll}
\hline Criteria & Gender & $\mathrm{n}$ & Mean & $\begin{array}{l}\text { Std. } \\
\text { deviation }\end{array}$ & $\begin{array}{l}\text { Std. error } \\
\text { mean }\end{array}$ & p-value \\
\hline Healing time & Female & 12 & 14.7500 & 4.86406 & 1.40413 & $0.958 \geq 0.05$ \\
& Male & 8 & 14.6250 & 5.62996 & 1.99049 & \\
\hline
\end{tabular}

No adverse drug reactions recorded to drugs prescribed for both groups.

\section{Discussion}

Oroantral communications and fistulas are complications often faced by oral and maxillofacial surgeons commonly after maxillary molars and premolars extraction due to their roots proximity with maxillary sinus [16].

In the following study, patients were suffer from OAF and treated with buccal flap according to the decision of their maxillofacial surgeon. To decrease post-operative discomfort and healing period, HA gel applied and prescribed to the patients due to its known ability to facilitate wound healing and wound protection without reported contraindications or serious interactions [17].

The result of the current study shows significant decrease in healing period for patients treated with HA gel when compared with patients treated without it. The following result may due to the proved ability of HA in stimulation of fibroblast proliferation and collagen fiber deposition that decrease healing time and promote rapid wound closure, especially in late stage of wound healing [18].
This finding agrees with Lee et al. [19]. study that found reduction in healing period and ulcers number when they apply $0.2 \% \mathrm{HA}$ gel twice daily for 2 weeks to patients have recurrent aphthous ulcerations and oral ulceration due to Behcet's disease. Furthermore, Romeo et al. [20] showed that applying 1.33\% HA and amino acids gel, topically 3 times a day for 1 week, can promote faster healing in patients who underwent an excisional biopsy of the oral soft tissues using laser than the control group. The previous study outcome similar to our study finding except that the gel applied in this study contains $0.2 \% \mathrm{HA}$ and used twice a day.

In contrast with the previous studies finding and the current one, Galli et al. [21] conducted a study using a single application of $0.8 \% \mathrm{HA}$ and found no improvement in healing when applied to different surgical site in the oral cavity. However, this may due to differences of incisional site size, as none of them is flap wound in addition to the frequency of gel application and concentration. Henceforth, well-documented clinical trials required to assess the efficiency of HA on reduction of healing period after surgical buccal flap closure of OAF.

No statistically significant differences between male and female observed in healing period for both treatment groups (Table 3). This finding comes with Rodanant et al. [22] who found no significant variation among male and female in healing outcome after 7 days of surgical wound closure. This finding accepted in regard of no anatomical or physiological differences between male and female in healing process postoperatively.

The limitation of this study was small sample size due to decision to review the records of patients treated by the same operator rather than multicenter study. We recommend doing multicenter evaluation for different type of oral surgical operation to assume the effect of $0.2 \% \mathrm{HA}$ gel on healing.

\section{Conclusion}

According to the present study finding, we conclude that topical application of $0.2 \% \mathrm{HA}$ gel to a surgical closure of OAF treated surgically by buccal flap reduce healing period without recorded adverse effect.

\section{Ethical Approval}

All procedures performed in studies involving human participants were in accordance with the ethical standards of the institutional board and with the 1964 Helsinki Declaration and its later improvements. 


\section{References}

1. Yilmaz T, Suslu AE, Gursel B. Treatment of oroantral fistula: Experience with 27 cases. Am J Otolaryngol. 2003;24(4):221-3. PMid:12884211

2. Güven O. A clinical study on oroantral fistulae. J Craniomaxillofac Surg. 1998;26(4):267-71.

PMid:9777507

3. Haas R, Watzak G, Baron M, Tepper G, Mailath G, Watzek G. A preliminary study of monocortical bone grafts for oroantral fistula closure. Oral Surg Oral Med Oral Pathol Oral Radiol Endod. 2003;96(3):263-6. https://doi.org/10.1016/ s1079-2104(03)00375-5

PMid: 12973280

4. Hernando J, Gallego L, Junquera L, Villarreal P. Oroantral communications. A retrospective analysis. Med Oral Patol Oral Cir Bucal. 2010;15(3):499-03. https://doi.org/10.4317/ medoral.15.e499

PMid:20038901

5. Dym H, Wolf JC. Oroantral communication. Oral Maxillofac Surg Clin North Am. 2012;24(2):239-47.

PMid:22503070

6. Peñarrocha-Diago M, García B, Gomez D, Balaguer J. Zygomatic bone graft for oral-antral communication closure and implant placement. J Oral Implantol. 2007;33(5):305-9. https:// doi.org/10.1563/1548-1336(2007)33[305:zbgfoc]2.0.co;2 PMid:17987864

7. Assad M, Bitar W, Alhaij MN. Closure of oroantral communication using platelet-rich fibrin: A report of two cases. Ann Maxillofac Surg. 2017;7(1):117-9.

PMid:28713748

8. Ogunsalu C. A new surgical management for oro-antral communication the resorbable guided tissue regeneration membrane-bone substitute sandwich technique. West Indian Med J. 2005;54(4):261. https://doi.org/10.1590/ s0043-31442005000400011

PMid:16312195

9. Parvini P, Obreja K, Sader R, Becker J, Schwarz F, Salti L. Surgical options in oroantral fistula management: A narrative review. Int J Implant Dent. 2018;4(1):40. https://doi.org/10.1186/ s40729-018-0152-4

PMid:30588578

10. Annaqiyah WK, Widiyanti $P$, Zaidan $A H$. Hyaluronic acid (HA)methylcellulose (MC)-based hydrogel with antibacterial AgNPs as a post-surgery intraperitoneal anti-adhesive physical barrier. J Int Dent Med Res. 2018;11(3):1110-15.

11. Noble PW. Hyaluronan and its catabolic products in tissue injury and repair. Matrix Biol. 2002;21(1):25-9. https://doi.org/10.1016/ s0945-053x(01)00184-6 PMid:11827789

12. Prosdocimi $M$, Bevilacqua $C$. Exogenous hyaluronic acid and wound healing: An updated vision. Panminerva Med.
2012;54(2):129-35.

PMid:22525567

13. Mesa FL, Aneiros J, Cabrera A, Bravo M, Caballero T, Revelles F, et al. Antiproliferative effect of topic hyaluronic acid gel. Study in gingival biopsies of patients with periodontal disease. Histol Histopathol. 2002;17(3):747-53.

PMid:12168783

14. Koray M, Ofluoglu D, Onal EA, Ozgul M, Ersev H, Yaltirik M, et al. Efficacy of hyaluronic acid spray on swelling, pain, and trismus after surgical extraction of impacted mandibular third molars. Int J Oral Maxillofac Surg. 2014;43(11):1399-403. https://doi.org/10.1016/j.ijom.2014.05.003

PMid:24924267

15. Rehrmann VA. Einemethodezurschliessung von kieferhohlenperforationen. Dtsch Zahnartl Wochenzeitschr. 1936;39:1136.

16. Khandelwal P, Hajira N. Management of oro-antral communication and fistula: Various surgical options. World $\mathrm{J}$ Plast Surg. 2017;6(1):3-8.

PMid:28289607

17. Rodriguez-Merchan EC. Intra articular injections of hyaluronic acid and other drugs in the knee joint. HSS J. 2013;9(2):180-2. https://doi.org/10.1007/s11420-012-9320-x

PMid:24426865

18. Palaia G, Tenore G, Tribolati L, Russo C, Gaimari G, Del Vecchio A, et al. Evaluation of wound healing and postoperative pain after oral mucosa laser biopsy with the aid of compound with chlorhexidine and sodium hyaluronate: A randomized double blind clinical trial. Clin Oral Investig. 2018;30(8):3141 51. https://doi.org/10.1007/s00784-018-2735-0

PMid:30374831

19. Lee JH, Jung JY, Bang D. The efficacy of topical $0.2 \%$ hyaluronic acid gel on recurrent oral ulcers: Comparison between recurrent aphthous ulcers and the oral ulcers of behçet's disease. J Eur Acad Dermatol Venereol. 2008;22(5):590-5. https://doi. org/10.1111/j.1468-3083.2007.02564.x

PMid: 18093111

20. Romeo U, Libotte F, Palaia G, Galanakis A, Gaimari G, Tenore $G$, et al. Oral soft tissue wound healing after laser surgery with or without a pool of amino acids and sodium hyaluronate: A randomized clinical study. Photomed Laser Surg. 2014;32(1):10-6. https://doi.org/10.1089/pho.2013.3509 PMid:24328847

21. Galli F, Zuffetti F, Capelli M, Fumagalli L, Parenti A, Testori T, et al. Hyaluronic acid to improve healing of surgical incisions in the oral cavity: A pilot multicentre placebo-controlled randomised clinical trial. Eur J Oral Implantol. 2008;1(3):199-206. PMid:20467622

22. Rodanant $P$, Wattanajitseree $K$, Shrestha $B$, Wongsirichat $N$. Pain and quality of life related to suture removal after 3 or 7 days at the extraction sites of impacted lower third molars. J Dent Anesth Pain Med. 2016;16(2):131-6. https://doi.org/10.17245/ jdapm.2016.16.2.131

PMid:28879306 